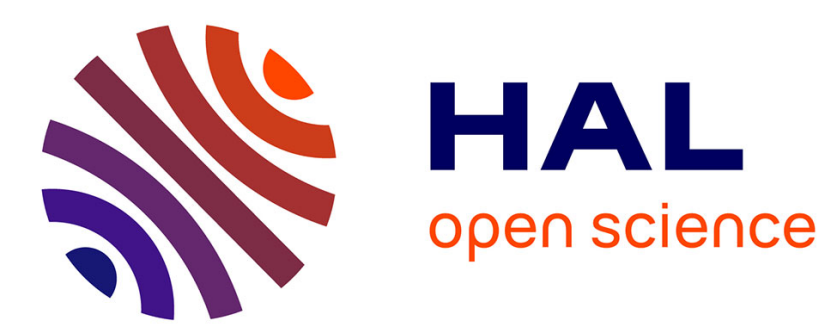

\title{
The workshop of Jacob de Wet (1610-1675) and his mass production of history painting
}

Angela Jager

\section{To cite this version:}

Angela Jager. The workshop of Jacob de Wet (1610-1675) and his mass production of history painting. Oud Holland, 2018. hprints-02186635v2

HAL Id: hprints-02186635

https://hal-hprints.archives-ouvertes.fr/hprints-02186635v2

Submitted on 31 Jul 2019

HAL is a multi-disciplinary open access archive for the deposit and dissemination of scientific research documents, whether they are published or not. The documents may come from teaching and research institutions in France or abroad, or from public or private research centers.
L'archive ouverte pluridisciplinaire HAL, est destinée au dépôt et à la diffusion de documents scientifiques de niveau recherche, publiés ou non, émanant des établissements d'enseignement et de recherche français ou étrangers, des laboratoires publics ou privés. 
Angela Jager, in: Oud Holland - Journal for Art of the Low Countries 131 (2018), vol. 2: pp. $67-108$

\section{The workshop of Jacob de Wet (1610-1675) and his mass production of history painting}

Over the course of his career, the history painter Jacob de Wet (I) (1610-1675) produced many paintings and trained lots of pupils. De Wet's oeuvre almost exclusively consists of subjects from the Old and New Testament, and makes use of a recognizable format that favors simple compositions, numerous small-scale figures and clear narratives. A large number of unsigned paintings closely resemble De Wet's compositions and figures. At auctions they are often attributed to De Wet or his circle. Among these depictions we find multiple versions of the same subject, some of which are identical but are painted on supports of varying dimensions and by different hands. This suggests standardized production by pupils and assistants. Some of these works are signed by registered apprentices of De Wet instead of the master.

This article investigates the standardized production of history painting in De Wet's studio. Following a brief introduction to De Wet, the text will focus on four subjects produced by his workshop. In these case studies, I will compare De Wet's prototypes to a large number of unsigned reproductions and signed variants. Next, I will give an overview of the different circumstances in which these De Wet-products were created in and outside his studio, based on De Wet's partially preserved administration and on probate inventories of two Amsterdam dealers in cheap paintings.

\section{De Wet, history painter in Haarlem}

Jacob de Wet was born around 1610 in Haarlem as the son of the Catholic bailiff Willem Jansz. de Wet and Marritge Jacobsdr. ${ }^{1}$ I have suggested elsewhere, that De Wet was perhaps instructed in painting by his grandfather Jan de Wet. ${ }^{2}$ Jacob de Wet registered at the Haarlem St. Luke's guild in 1632, and from this year onwards he was allowed to sign works and accept pupils. ${ }^{3}$ Between 1638 and 1670 he listed as many as 37 pupils, whose names are known through administrative notes that are preserved in a sketchbook in the Noord-Hollands Archief, which will be discussed below. ${ }^{4}$ For now, it suffices that only two of the listed pupils left behind a significant number of history paintings: Adriaen Gael (II) (1618-1665) and Adriaen Verdoel (I) (1623-1675), who joined De Wet's workshop in 1640 and 1641 
respectively. De Wet's reputation in Haarlem was quite strong and he was honored several times with a position in the Haarlem St. Luke's guild $\left(1645,1661\right.$, and 1662). ${ }^{5}$ Through regular visits he acquired a reputation in Amsterdam as well, where he was chosen by the alderman as one of the fifteen 'best connoisseurs' to judge the Italian paintings of Gerrit Uylenburgh (1671). ${ }^{6}$

There were several artists in the De Wet family, two of whom deserve specific mention. ${ }^{7}$ Jacob's brother Gerrit de Wet (c. 1610-1674) was also a painter. He adopted the manner of his brother quite accurately, and he likely worked in De Wet's workshop in Haarlem until 1663. That year, Gerrit settles his guild dues for the preceding ten years and left town for Leiden, where he got married and started a workshop on the Steenschuur. ${ }^{8}$ Gerrit's earliest known paintings date from 1640 and he is first mentioned in the Haarlem guild records in 1643, when he was requested to 'finally' pay his dues. ${ }^{9}$ De Wet's oldest son, Jacob de Wet (II) (c. 1640/42-1697) trained as a painter with his father at an early age. ${ }^{10}$ The preserved administrative notes in the Haarlem sketchbook mention De Wet's (II) works being sold under his own name in 1657 when he was at most 17 years old. He probably worked in his father's workshop until his marriage in 1668, after which he moved to Amsterdam. ${ }^{11}$ From 1673 onwards, De Wet (II) painted on commission in Scotland, and included the Scottish court among his clients. ${ }^{12}$ There he distanced himself from his father's manner and adopted a more academic style; although his only dated Dutch work (1670) suggests that this development started in Amsterdam. ${ }^{13}$ Works by De Wet (II) in his father's manner are signed 'De Wet de Jonge', but after transitioning to this new style he reduced his signature to 'De Wet'.

\section{Four case studies of De Wet's production}

De Wet's oeuvre consists mainly of biblical narratives, of which many subjects are represented multiple times. For his Gemälde der Rembrandt-Schüler (1983-c. 1994), Werner Sumowski gathered images of 63 paintings by De Wet and since the time of this publication more have surfaced, including many unsigned paintings attributed to De Wet or his 'circle'. 14 De Wet's autograph works are of considerably better quality than the many anonymous ones, but there is clearly a connection between both. The unsigned paintings resemble De Wet's compositions and, at times, replicate the same organization and structure as the artist's signed paintings, but are often executed by less talented hands, suggesting the involvement of pupils and assistants. The following case studies will analyze four frequently recurring subjects in 
De Wet's oeuvre: The triumph of Mordecai; The feeding of the five thousand; The queen of Sheba visiting Solomon; and Christ and the woman taken in adultery. Surveying the oeuvres of the artist and his circle, I relate De Wet's originals to various versions of the same composition and trace the workshop's methods of mass production. This requires the inclusion of many illustrations. Many of these paintings have not been seen for a long time and not all photos are up to par. However, they are good enough to serve the purpose of comparison of compositions and individual motifs while the sheer number of surviving paintings demonstrates the mass production I aim to illuminate.

\section{The triumph of Mordecai: repetitions and variants}

The Book of Esther (6:11) recounts Haman's plot to kill Mordechai, who was instead honored at the king's instructions in a parade through the streets. Early modern depictions of The triumph of Mordecai often depict a similar moment in this Old Testament story, featuring Mordecai on a horse and Haman walking him into the city. In the signed painting by De Wet, Mordecai and Haman are depicted in the center of the composition, with a crowd of beholders to their left (fig. 1). The position of the horse and Haman bear close resemblance to Pieter Lastman's treatment of this subject in 1617 (fig. 2), but De Wet uses a more distant perspective. This makes us mere spectators to the entire scene (as was common for De Wet) rather than participants in the depicted audience as is the case with Lastman's work. Judging by the man at the bottom right of the composition, who is kneeling and taking off his hat, De Wet must also have been familiar with an engraving by Lucas van Leyden (1494-1533) of the same subject, or Rembrandt's later print, which borrows from the sixteenth-century master (figs. 3 and 4). ${ }^{15}$ A second version of The triumph of Mordecai dated 1637 depicts Mordecai and Haman in a similar fashion (fig. 5), except that Haman is turning his head towards the crowd. ${ }^{16}$ The stooping figure, which De Wet adopted from Van Leyden's print, is depicted again in the same place at the bottom right. Other figures recur but are repositioned, such as the soldiers, who have been placed at the right side by the gate.

Four unsigned paintings of The triumph of Mordecai on supports of different dimensions bear a composition identical to De Wet's 1637 painting. They are too weak in execution to be by the master himself, but they are clearly based on this work (figs. 6-9). However, they reverse the motif of Mordecai and Haman. These paintings also introduce two soldiers on horses following Mordecai on the left side, and a young man climbing a landmark in the middle. At the far right is a bridge with a large crowd. The figure types in the four 
unsigned versions are very similar to De Wet's image, and we see again the stooping person on the left, though his proportions are somewhat incorrect, and a woman with a child, who is kneeling to honor Mordecai in the right foreground of the painting.

The four unsigned depictions are presumably copies of a lost prototype by De Wet, or a depiction specifically designed by De Wet for reproduction by his assistants. The paintings show differences in style and execution, which indicates that different painters produced the exact same scene. For example, the execution of the kneeling woman and child at the right differs greatly from a version auctioned in New York or the one recorded in a private collection in Den Bosch (compare figs. 10 to 11). In the latter, the woman wears a headpiece with a soft veil, and her face is smooth and proportionately executed. Little, round brush strokes and dots are used to decorate the child's dress and the woman's underdress. In contrast, the painter of the New York piece applied no decorations to the child's dress and only a few crude stripes to the woman's underdress. She wears no headpiece or veil and her face is painted quickly and disproportionately. In addition, this painter used a few quick highlights to accentuate lighter zones on her sleeve and skirt, while the painter of the Den Bosch version gradually fades dark into light.

By overlaying the photographs of the four unsigned paintings of the same scene in Adobe Photoshop, I was able to demonstrate that these four paintings of different dimensions depict The triumph of Mordecai in the same proportions. ${ }^{17}$ An overlay was made by cutting the composition on all sides to a specific point, which allowed for possible reductions of the panel at a later date. ${ }^{18}$ The four images were resized, processed with a glowing edges-filter to accentuate the contours. A transparency masks was used to hide irrelevant details and background elements, and finally the lines were colored in green, blue, black, and red (fig. 12). Although distinctions in quality and focal point of the photographs impacted this method's results, the matching proportions of these paintings are evident and suggest the use of a reproduction method, probably a grid, which, as we shall see, was a strategy used repeatedly with a range of subjects to increase production. ${ }^{19}$

De Wet's pupils Gael and Verdoel both produced painted works after De Wet's The triumph of Mordecai (figs. 13 and 14). Gael's version demonstrates that he had the same prototype at his disposal as the anonymous painters of the above mentioned reproductions, as evidenced by the presence of the bridge with a large crowd, the kneeling woman and her child, and the broken column to the bottom right (fig. 13). Gael deviated from the design by using another posture for the horse and changing the attitude of Haman, who is now standing next to the horse, announcing his message to the public more vigorously. He also included 
new additions, such as the soldier restraining the crowd on the left. Verdoel's variant shows more similarities with the 1637 dated De Wet (figs. 5 and 14). Next to the gateway, he adopted the motif of the horse and Haman, but mirrors the arrangement, as found in the four anonymous works. The painter, however, added many new supporting characters, including a man with a trumpet who is also found in the print by Van Leyden, which must have been available for study purposes in De Wet's workshop.

The unsigned paintings of The triumph of Mordecai are simplified versions of a presumable original by De Wet. The same design was copied by different hands and on different sized supports, done to scale. Neither Gael's nor Verdoel's version of The triumph of Mordecai can be characterized as slavish copies; they show additions to the established concept and design and were rather 'free variants'. Initially they remind us of the variations made by pupils and assistants after prototypes in Rembrandt's studio. However, these free variants - termed 'satellites' by Ernst van de Wetering - were created next to Rembrandt's easel and were never signed by the assistant. ${ }^{20}$ The signatures on the variants by Gael and Verdoel are therefore distinguishing characteristics.

\section{The feeding of the five thousand: repetition and adaptation}

The feeding of the five thousand (John 6:1-14) tells how Jesus fed a multitude with only five barley loaves and two small fish and is an unusual subject in seventeenth-century painting. ${ }^{21}$ De Wet's treatment of this narrative, preserved in a work that is now found in the collection of the Hermitage in St. Petersburg (fig. 15), is set against the backdrop of the mountain to which Christ would retreat after feeding the crowd. De Wet uses this mountain to suggest a large gathering of people who disappear into the landscape. Christ is one of the few characters in the painting standing upright in a distinct pose, and thus immediately attracts the viewer's attention. He is depicted holding out a loaf of bread while turning his face towards the sky, with a child kneeling before him holding a basket filled with bread, next to which lay two fish. The vertical format and the rather steep mountain create a strong diagonal from bottom left to upper right. Only Christ and the figures around him are explicitly articulated by means of powerful colors and a thick application of paint. The characters to the left and right behind the scene are painted in a wet-in-wet technique using the same colors as the background.

Four unsigned paintings of The feeding of the five thousand, all of which feature a (nearly) identical arrangement, are too weak in execution to be De Wet, but are evidently based on his signed work (figs. 16-19). In particular, Christ's pose and the steep mountain are 
shared among the five works, with the exception of one unsigned work in which the top of the mountain is missing, causing Christ's head to stand out against the dark, cloudy sky (fig. 19). Was this a deliberate choice, or did the anonymous painter forget to finish the mountain? The four 'repetitions' were executed in different sizes - the largest measures 118.1 x $163.8 \mathrm{~cm}$ and painted on canvas - but the proportions of the characters remain intact. This demonstrates that the scene was repeated to scale, as is the case with the unsigned versions of The triumph of Mordecai.

These workshop copies are rarely on display in public collections, and therefore not easily accessible. Fortunately, one of the unsigned versions of The feeding of the five thousand in a private collection could be studied in more detail (fig. 18). ${ }^{22}$ This large panel consists of two planks and measures $72.9 \times 138.3 \mathrm{~cm}$. Wormholes can be seen along the upper edge of the panel, indicating that a top plank is missing due to wood worms. This can also be deduced from the composition on the front, which is awkwardly cut halfway through the mountain. The background colors are thinly applied and fluently painted so that the ground beneath is visible between the brushwork. The figures and the contours are applied directly on the ground, suggesting that the painter had a clear example. Infrared reflectography demonstrate that the painter did not make any underdrawing in black chalk, paint or lead pencil, yet there were no alterations in his painting process. We may therefore assume that he made use of an underdrawing or a grid in another material, undetectable by infrared imaging.

De Wet's son Jacob painted a larger, horizontal version of his father's prototype (fig. 20). De Wet (II) adopted several figures from his father's painting, including Jesus holding a loaf of bread, the woman with a baby and the woman on the bottom left portrayed on her back. He also made some changes to his father's design, such as the child on his knees, who holds fish instead of bread, while the loaves lay on the floor next to him. De Wet (II) also changed his father's mountainous landscape into hills with lush vegetation. As is the case with Gael's and Verdoel's variants of The triumph of Mordecai, De Wet's (II) work may also be labeled as a 'free variant', . The composition and figure types and narrative elements are adopted from his father's prototype, but De Wet (II) made changes and introduced other features as well.

Christ is central to this biblical narrative, and the characters around him fulfill a supporting role, with the exception of the kneeling boy with a loaf of bread in his hand. This made the composition of The feeding of the five thousand easy to adapt to different stories by simply changing attributes. This happens in two paintings by Gael, in composition similar to The feeding of the five thousand but they depict Pharaoh's army engulfed in the Red Sea 
(Exodus 14:26) instead (figs. 21 and 22). Here we see Moses in the same position and pose as Christ, but he holds a staff instead of the loaf of bread. The same overall design, sometimes mirrored (fig. 22), could thus be reused with minimal adjustments. Narrative-specific elements, such as the Red Sea and a drowning Pharaoh, are easily accommodated to the side of the mountain. The motif of the woman with a baby, on the other hand, appears on both The feeding of the five thousand and Pharaoh's army engulfed in the Red Sea.

\section{The queen of Sheba visits Solomon: stock figures and standardized compositions}

The use of similar compositions and figures for different stories clearly was a standard practice in the workshop of De Wet, as another example of an endlessly repeated subject from his workshop shows: The queen of Sheba visiting Solomon (I Kings 10: 1-13). In this narrative the queen of Sheba travels to Jerusalem to test King Solomon's famed wisdom and arrives at his throne bearing spices and precious stones. The history of Solomon, which also include topics such as Solomon blessing David as his successor on the instigation of Bathsheba (1 Kings 1:28-33) and Solomon's idolatry (1 Kings 11:7-8), was frequently depicted in De Wet's workshop, but rarely addressed in the production of other workshops at the time. In fact, aside from De Wet's oeuvre and that of a few other painters - such as Willem de Poorter (1608-in or after 1649) and Salomon Koninck (1609-1656) - depictions with Solomon were relatively rare in the seventeenth-century Netherlands. ${ }^{23}$

De Wet signed at least three different versions of The queen of Sheba visiting Solomon (figs. 23-25), but only one is dated (1635). This painting corresponds to De Poorter's depiction of the same subject, particularly in the arrangement of the composition (though reversed), the background, the figures carrying the queen's veil and the seated man in the corner (figs. 25 to 26). In the late 1620s, Rembrandt had developed the compositional scheme of small figures in a dark interior, with an authoritative figure placed on a set of steps looking down onto a group of standing and kneeling figures and framed by repoussoirs in one of the corners. ${ }^{24}$ De Wet and De Poorter used this format throughout their entire careers. Eric Jan Sluijter therefore suggested that the two painters must have been simultaneously present in Hendrick Uylenburgh's (1587-1661) studio in the early 1630s, where they were able to study and copy Rembrandt's work. ${ }^{25}$ Indeed, De Wet and De Poorter frequently produced history paintings with the same subjects and comparable compositions in the 1630s and early 1640s.

Two unsigned panels of The queen of Sheba visiting Solomon (figs. 27 and 28) are undoubtedly based on the works of De Wet. Not only is the arrangement similar, but several 
figures also feature in De Wet's paintings. The man with his back towards the viewer was adopted from a De Wet painting in Zürich (fig. 23), whereas the seated Solomon, with a rod held loosely in his hand, matches a figure in a painting in London (fig. 24). The posture of the queen of Sheba, however, is comparable to the figure in De Poorter's version. The two unsigned paintings are presumably copies of an unknown prototype by De Wet, or an example he specifically designed to be reproduced, as argued in the case of The triumph of Mordecai and The feeding of the five thousand. Again, the works repeat the composition in different sizes, done to scale, and suggest the use of a reproduction method (such as a grid).

A comparison of these two unsigned panels with three unsigned versions of Solomon blessing David as his successor on the instigation of Bathsheba (figs. 29-31) provides more information concerning the manufacturing of paintings in De Wet's workshop. The composition, background with the gate and colonnade, and Bathsheba's position with respect to the entire composition, correspond closely to the two anonymous depictions of The queen of Sheba visiting Solomon (figs. 27 and 28). Both narratives show a central group with a female protagonist in the same pose, a servant carrying her train, and the three figures following behind. The outlines of the group to the right are comparable, even though the figures by the throne of Solomon are elevated in relation to the man at the table and the chambermaid by the bed of king David. Note that the posture of this seated man and the bent figure of David can also be found in the work featuring Queen Esther before king Ahasueros (Esther 5:2) (fig. 32).

De Wet's pictorial arrangements and dense figural groups seem to have been designed with the premeditation to be adaptable to a number of different subjects. The design allowed for the contours of the figural group to be drawn, and the background painted, before the subject was definite. In this way the composition could be set up easily and quickly in advance, speeding up the painting process while retaining maximum iconographic flexibility. This allowed De Wet to meet current demand with a limited number of standardized compositions. One of the paintings of Solomon blessing David as his successor on the instigation of Bathsheba (fig. 29) was studied with infrared reflectography in an attempt to confirm the hypothesis. ${ }^{26}$ Although no underdrawing in black was detectable in the figures, IRR did expose a predetermined design; the figures were reserved in the background and painted directly on the ground.

This painting sequence occurred more often in De Wet's workshop, as The sacrifice of the daughter of Jephtah (Judges 10:39) (fig. 33) by Gerrit de Wet in the collection of the Statens Museum for Kunst in Copenhagen shows. ${ }^{27}$ The artist first painted the background 
with rather quick brush strokes around the upper contours of the planned central group. The figures in the back and the architecture were then applied with simple brush strokes and wetin-wet technique into the background. The central figures were painted only after the background was in place. Certain details, such as the hair of Jephtah's daughter, were done on top of the dark paint. The man in the lower left corner, whose outlines do not touch the background, was emphasized by the application of dark contours around him. The crying man in the foreground was added to the depiction in a later stage of the process. He is identical to a figure in Gerrit de Wet's The presentation in the temple (fig. 34).

At least one case illustrates the use of drawings in De Wet's workshop. De Wet's drawing of The queen of Sheba visiting Solomon (fig. 35) served as an example for two paintings, one of which is questionably signed and dated 'J. de Wet 1654' (figs. 36 and 37). ${ }^{28}$ The upper portions of both paintings include more compositional elements than are found in the drawing, suggesting that it must have been cut down. A third painting with an unclear monogram, here interpreted as 'DP', largely repeats the staffage from the lower left corner to the upper right corner (fig. 38). The painter changed the figures in the background to the left and Solomon's pose. Moreover, the artist added richer clothes and jewels, making the scene more elaborate. This monogrammed version includes changes to the original design and the introduction of new elements, and can therefore be identified as a free variant, similar to those Gael and Verdoel produced after De Wet's designs.

Gael and Verdoel also painted variants of The queen of Sheba visiting Solomon, and their depictions largely correspond to De Wet's 1635 type (compare figs. 39-41 to fig. 25). As stated earlier, Gael entered the workshop in 1640 and Verdoel in 1641, proving that prototypes were used at least for five years. The original was not slavishly copied by Gael and Verdoel. However, all three variants demonstrate the reuse of its composition and other narrative elements.

\section{Christ and the Woman taken in Adultery: changing the format}

In the biblical account of Christ and the woman taken in adultery (John 8:2-11) a group of scribes and Pharisees bring a woman to Jesus, accuse her of committing adultery, and ask whether she should be stoned. Jesus replies that the one who is without sin should cast the first stone. This is a very different story from The queen of Sheba visiting Solomon, but De Wet's depictions of these two narratives are quite similar in composition. In both scenes, the viewer's attention is drawn to a woman kneeling before a man who is portrayed on a higher 
picture plane. The central configuration is surrounded by onlookers in a dark interior.

However, specific alterations were needed to change the queen of Sheba into the adulterous woman.

There are multiple versions of Christ and the woman taken in adultery signed by De Wet, but we will focus on the two that served as prototypes for mass production. The first example is painted on a large vertical canvas and shows a vast, dark, and crowded temple. On the stairs we see a central scene taking place, while in the background on a higher level a scene with a priest is cast in shadow (fig. 42). De Wet surely had Rembrandt's depiction from 1644 in mind (fig. 43). De Wet's woman has her hands in her lap and is held by a soldier, while she kneels before Christ. Two men sit on Christ's right, while on his left, a Pharisee is leaning against a stick. In the foreground a boy is getting down on his knees in front of a basket of stones. He notably resembles the stooping Van Leyden figure, which we have seen repurposed more than once (figs. 1, 5, 6-9, 21, 35, 36-38).

The other prototype is a smaller horizontal canvas (fig. 44) in which the Pharisee sits beside Christ with a book on his lap, and points towards the woman. The adulteress kneels before Christ and clasps her hands begging for forgiveness. This pose is borrowed in reverse from Rembrandt's Judas returning the thirty silver pieces (Matthew 27:3-5) (fig. 45): the scribe in Rembrandt's painting, seen from the back with his face towards the scene, is depicted in De Wet's work as well. Jacob de Wet was perfectly familiar with Rembrandt's Judas, which is further demonstrated by his own depictions of Judas returning the thirty silver pieces in 1636 and 1642 (figs. 46 and 47).

Jacob's brother Gerrit de Wet painted a vertical version of this arrangement in Christ and the woman taken in adultery, which features an almost exact copy of the main composition and background (compare figs. 48 to 44). He only made a few adjustments to transfer his brother's horizontal arrangement to a vertical format by placing the characters in the central group closer together and replacing the seated figures at the table with a group of standing men. He also used an alternative position for the hands of the kneeling adulteress; they are now crossed over her chest. Gerrit used this pose of the adulteress in at least one other case, in his portrayal of Abigail in David and Abigail (1 Samuel 25:23) (fig. 49). In this painting, David's bearing shows strong similarities with Christ in Christ and the woman taken in adultery.

There are many anonymous repetitions of Christ and the woman taken in adultery (figs. 50-58), although not all can be ascertained to come from De Wet's workshop. As we will see, a number may come from another source. In any case, they all share a simplified 
background and composition, and the three main characters (the kneeling adulteress, standing Christ, and the seated Pharisee) are repeatedly adopted directly from Jacob de Wet's horizontal prototype (fig. 44). The adulteress keeps her hands down, as seen in the vertical version (fig. 42). The Pharisee does not point his hand towards the woman (perhaps this was considered too difficult to copy?). The priest and the throne on the elevation seen in the backright of the prototype are omitted in all the repetitions, but the ornaments that decorate the throne are copied from the original source, creating a strangely decorated wall. Moreover, the two characters at the table in the prototype are missing, while a few new figures have been added. The man who presents the adulteress is not carrying a weapon, and the boy seen to the left with the basket full of stones has been replaced by an old man. He bends over to pick up a rock for the stoning of the adulteress, a motif known from another Christ and the woman taken in adultery signed by De Wet (fig. 59). A richly attired man with a walking stick at the left is observing the scene and is found in the variant works as well.

Many anonymous repeated compositions are painted on supports of different sizes. At least three of these seem to be missing the top of the panel (figs. 52, 54 and 57). The rectangular format of one of the works is changed into a rounded top that corresponds to Rembrandt's original from 1644 (compare figs. 58 to 43) ${ }^{29}$ Unfortunately, the quality of the only known photograph of this work is not good enough to determine how the painter transferred the composition and the staffage to this unusual format, but it does allow us to see that this subject was used in a variety of ways. Two of these paintings bear a date on the cap of the Pharisee; 1650 and 1657 (figs. 56 and 57), again demonstrating that the same composition was produced by the workshop over the course of several years.

\section{Mass production of De Wet's designs}

The preceding analyses of the four subjects show that De Wet's signed originals often occur in two ways: unsigned simplified versions and signed free variants. The same design was identically repeated by different hands for several years and available on different sizes and formats to scale, most probably created by the use of a grid. Compositions, backgrounds and figure types were created with the purpose of reuse and transferability to other scenes. All of this clearly points to mass production.

At the same time, there are also several free variants of these originals, signed by De Wet's pupils Gael and Verdoel. These variants suggest that Gael and Verdoel were allowed, and maybe even encouraged, to alter the compositions of the master. They added new 
elements and signed them with their own signature. This contradicts the general assumption that a studio work was signed by the master only. ${ }^{30}$

Gael had access to both De Wet's originals and the simplified designs, as is demonstrated in his depiction of The triumph of Mordecai, which includes elements from the anonymous paintings of the subject (figs. 6-9, 13). This indicates that both the anonymous repetitions and the free variants were created in De Wet's workshop. The anonymous versions were presumably produced as (cheaper) reproductions for the art market and painted by young pupils. However, the question of why some assistants were apparently allowed to change the master's prototype and sign these with their own names remains. The following paragraphs will study the preserved administrative notes of De Wet's workshop, the careers of Gael and Verdoel and the market for De Wet's paintings to understand the relationship between the different types of versions produced by De Wet's and his circle.

\section{De Wet's pupils and assistants}

The most important written source for understanding Jacob de Wet's workshop is the aforementioned collection of administrative notes, preserved in a sketchbook in the NoordHollands Archief. ${ }^{31}$ The sketchbook, compiled at a later date, consists mainly of topographical landscape drawings of Haarlem and surroundings, figure studies, and depictions of biblical scenes. ${ }^{32}$ In the few pages of written records included in this book, De Wet listed as many as 37 pupils between 1638 and 1670, and specified whether they studied drawing or painting, the dates of their entry, and the fees he charged for instruction (appendix 1). ${ }^{33}$ Unfortunately, the pages with the entries from 1645-1649 and 1657-1659 are missing, and it is possible that a page prior to the first entry in 1638 has also been lost. De Wet was allowed to have students from 1632, when he registered as a master painter in the Haarlem St. Luke's guild. ${ }^{34}$ Each page lists around thirteen names, providing an indication of the number of pupils he trained throughout his career. The total number of apprentices may have approached 65 .

In his notes, De Wet specified the annual student fee but did not indicate the period of training. Drawing apprentices were charged forty guilders annually, painting apprentices 48 guilders, but De Wet increased his rates to 48 and sixty guilders respectively somewhere between 1644 and $1650 .{ }^{35}$ In comparison with other known training rates from seventeenthcentury Dutch painters, these fees are consistent with the average, but substantially less than those associated with highly-esteemed masters. ${ }^{36}$ Rembrandt, for example, charged 100 guilders for his tuition. ${ }^{37}$ De Wet calculated room and board separately, at 208 guilders 
annually. This relatively high price may account for the low number of students who made use of this option. Only three are registered as receiving room and board ('in de kost ghekomen'): the Swedish student Kort Withold in 1642; one 'Luycas Frank' in 1650, and once more in 1655; and Rochus van Veen (c. 1640-1693) in 1668. De Wet's training activities must have provided him with a respectable and steady income.

The majority of De Wet's students are not well known, in contrast to Rembrandt's pupils (appendix 1). The only two who would become truly successful masters are Paulus Potter (1625-1654) and Job Adriaensz. Berckheyde (1630-1693). Potter entered De Wet's studio 'to paint' in 1642 and Berckheyde 'to draw' in $1644 .{ }^{38}$ Neither painter is known for their history paintings, but both seem to have painted these types of subjects at the outset of their careers. Potter's first signed works are histories, one of which even originates prior to his time with De Wet, while he was training under his father Pieter Potter (1597/1600-1652), who occasionally made history paintings himself. ${ }^{39}$ Berckheyde also depicted histories sporadically throughout his career. The 1653 inventory of the Amsterdam art dealer Pieter van Meldert lists 'A history of the steward in ebony frame, by Jop Bercheijer' (Parable of the unjust steward $).{ }^{40}$ Berckheyde paid his guild entrance fee one year later in $1654 .{ }^{41}$ Interestingly, the Staatliches Museum Schwerin owns a signed and dated Christ blessing the children brought by their mothers from 1662 by Berckheyde, executed in De Wet's style (fig. 60). ${ }^{42}$ This painting dates from almost twenty years after the start of his apprenticeship with De Wet, and it remains unclear why he resorted to his old master's manner at this stage of his career.

It is likely that most of De Wet's pupils simply never had a career in painting and either turned to other professions or made generic paintings in anonymity for the art market. Most of the other students in appendix 1 are unknown and absent from RKDartists, as the majority did not leave behind signed paintings or drawings. Remarkably, between 1660 and 1667, De Wet only listed drawing students. At least two of whom became beeltsnijders; Abraham Snellaert (1646-1693) and Huybert Leenderts van Rijn. ${ }^{43}$ Perhaps some of the other unknown students were dilettantes and studied with De Wet for non-professional reasons, as Marion Boers-Goossens has suggested. ${ }^{44}$

Despite this seemingly meagre career perspective following training under De Wet, his large number of pupils suggests that he was a fairly popular master, and two instances can be found in which students left their current master in favor of De Wet. Kort Withold, who is mentioned above, only trained with Philips Wouwerman (1619-1668) for a few days before relocating to De Wet's studio. Guilljeam le Febre received seven months of instruction by 
Nicolaes Berchem (1621/1622- 1683) before his transfer to De Wet. ${ }^{45}$ Le Febre's aborted training with Berchem is particularly interesting because this apprenticeship has been used in modern scholarship to suggest that Berchem could not have traveled to Italy in the period 1642-1645, an interpretation that now needs to be revisited. ${ }^{46}$

\section{De Wet's vrije gasten: Adriaen Gael and Adriaen Verdoel}

Adriaen Gael (II) and Adriaen Verdoel (I) are both registered as pupils in De Wet's workshop administration. Gael entered the workshop in 1640 'to paint' ('te schilderen ghecomen') at the age of 22 , which suggests that he was not a novice. ${ }^{47}$ Gael came from a large family of painters, and he was probably trained primarily by his father Adriaen Gael (I) (1585-1660), his uncle Cornelis Adriaensz. Gael (I) (1589/1590-1672), or his cousin Barent Gael (1630/1635-1698).$^{48}$ His only dated works, from 1643 and 1644, depict De Wet-like subjects, compositions and figure types. ${ }^{49} \mathrm{He}$ did not register as a master painter in the Haarlem guild until 1660, at which time he inherited the workshop inventory, painters' equipment and 1500 guilders from his recently deceased father. ${ }^{50}$ It is tempting to assume that Gael worked in the family business until he became an independent master, but his surviving paintings are all painted in De Wet's manner. ${ }^{51}$

Being the son of a miller, Verdoel did not come from an artistic family ${ }^{52}$ In 1641, at the age of 18 , he started 'to learn how to paint' ('om te leren schilderen') under De Wet. ${ }^{53}$ As was the case with Gael, Verdoel was older than a typical apprentice, and it is possible that he had been instructed in drawing before arriving at De Wet's workshop. ${ }^{54}$ Two documents suggest continued association between De Wet and Verdoel following his apprenticeship, including a document that records De Wet's position as guarantee for Verdoel's legal costs in 1644 , and another in which Verdoel acted as a witness for De Wet in $1646 .{ }^{55}$ Verdoel may have even remained connected to the workshop until 1649, when he became a member of the Haarlem St. Luke's Guild. ${ }^{56}$ Most works signed by Verdoel are painted in the style of De Wet. $^{57}$

As we have seen, Gael and Verdoel adopted De Wet's manner, style and compositions quite literally and the paintings they produced in the workshop were directly based on De Wet's designs, though often altered and signed with their own names. This seemingly unusual practice probably followed from a regulation of the Haarlem St. Luke's Guild, which stipulated that before registering as masters, painters were required to have completed at least three years training and have worked at least one year as a vrije gast or 'guest-painter in 
residence' in another master's workshop. ${ }^{58}$ These guest painters made works in the style of their host and were obligated to sell their products through his shop. In turn, they were allowed to sign their works with their own names. ${ }^{59}$ Gael and Verdoel presumably continued in De Wet's workshop as vrije gasten after completing their primary training but before registering as master painters. The signed variants were likely created within the context of the vrije gast apprenticeships.

\section{De Wet's retailers: production outside of his workshop}

Jacob de Wet's workshop primarily catered to the Amsterdam market, as is suggested by several seventeenth-century inventories of art dealers in which works by De Wet, his family and his pupils are mentioned. De Wet's manner appears to have been rather popular in Amsterdam, where it was the main example for many (mediocre) history painters throughout the seventeenth century, as Sluijter has demonstrated. ${ }^{60}$

The art dealers Pieter van Meldert (c. 1619-1663) and Mathijs Hals (1605-1661) both stocked several paintings from De Wet's workshop. Van Meldert was mentioned above as the owner of Berckheyde's history painting. ${ }^{61}$ The inventory of his shop on the Prinsengracht (between the present-day Laurier- en Rozenstraat) was drawn up after his wife's death in 1653 and lists a painting by Jacob de Wet (I), a copy after him, a work by Gerrit de Wet and one by Adriaen Gael. ${ }^{62}$ A note in De Wet's sketchbook from 1658 mentions the supply of two paintings by his son to Van Meldert for the price of 16 guilders. ${ }^{63}$ This indicates that there may have been regular business contact between them in subsequent years. The art dealer Matthijs Hals, located in the Pijlsteeg, had one painting by De Wet in stock and two by De Wet's son in $1662 .^{64}$

The dealers Cornelis Doeck (c. 1613-1664) and Hendrick Meijeringh (1639-1687) were specialist suppliers of inexpensive history paintings in Amsterdam and had enormous stocks-in-trade, including many works by De Wet and his pupils. ${ }^{65}$ Doeck's shop on the Nieuwmarkt (on the corner of the Kloveniersburgwal and the Koestraat) was inventoried in 1667, and contained as many as 576 paintings. Meijeringh's shop, which was located only two doors down from Doeck on the Kloveniersburgwal, held 499 paintings in 1687.66

The Doeck inventory mentions 28 paintings by five different history painters connected to Jacob de Wet (appendix 2), who must have supplied Doeck on a regular basis. ${ }^{67}$ The inventory includes works by De Wet, his brother, his son, and Verdoel; and no fewer than twelve paintings are attributed to a certain Pieter Wiggersz. (1632-1673). Wiggersz was born 
in Gdańsk and entered De Wet's workshop in 1656 'to paint' ('te schilderen ghekomen'). ${ }^{68}$ As far as we know, none of his works have survived. Most probably the paintings by Wiggersz. listed in Doeck's inventory were signed, and he may have been a vrije gast in De Wet's workshop, like Gael and Verdoel. ${ }^{69}$

The inventory of Meijeringh's shop lists 26 paintings from De Wet's studio including those executed by De Wet, his brother, his son, Verdoel and as many as eleven works by Gael (appendix 3). These paintings were mostly found in Meijeringh's attic studio, where they seem to have functioned as examples for his own employees, who mass-produced history paintings for the shop. ${ }^{70}$ This makes it quite likely that a number of the copies and variants after De Wet were actually created outside of De Wet's studio in Meijeringh's, and maybe Doeck's workshop. ${ }^{71}$ The Meijeringh inventory suggests that the paintings in his shop were ordered by size, given that contemporary names of standard sizes such as tien stuijvers maet and salvatoorsmaten serve as headings for the paintings. ${ }^{72}$ Most biblical scenes in Doeck's and Meijeringh's shops were represented multiple times and available in several of these standard sizes, which recalls the anonymous works after De Wet's designs that were done to scale on supports of different dimensions.

We can safely assume that De Wet sold these Amsterdam dealers paintings by his brother Gerrit, his son Jacob (II) and his more advanced pupils Gael, Verdoel and perhaps Wiggertsz. The particular cases of Van Meldert and Doeck even suggest a regular supply. Boers-Goosens has suggested that as retailers art dealers must have paid De Wet less compared to private buyers, based on the prices of paintings listed in the De Wet sketchbook. ${ }^{73}$ I would like to propose that the asking price of these paintings depended primarily on their dimensions. ${ }^{74}$ Boers-Goosens based her suggestion on the sale of 'een doeckie' depicting Amaryllis and Mirtillo and a 'peneel' with Rebecca for 54 guilders to the painter and art dealer Wouter Knijff (1662). A number of private collectors paid significantly higher prices. 'Menheer Emrick' paid sixty guilders for an Iphigenia on 'daeldersdoeck' (1671), Willem Sickx 72 guilders for a Christ preaching from a boat and 68 guilders for Paul and Barnabas (no date provided), and 'Van der Stel' hundred guilders for Europa (no date). ${ }^{75}$ These were sale prices, not taxations. At first glance, this seems to indicate that art dealers paid less for their purchases. However, we arrive at a different conclusion when we examine the stated sizes of the painting supports. A 'doeckie' is a diminutive of canvas and indicates a small painting support, whereas the expensive 'daeldersdoeck' was the largest standard support size available. ${ }^{76}$ As a rule, most panel supports were smaller than canvas supports, 
and only the largest paintings were done on canvas, as we have seen in the four case studies examined above. ${ }^{77}$

De Wet would have sold paintings by his pupils and employees for a considerably smaller amount than his own works. These would have acquired additional value through his reputation, which was substantial in Haarlem and Amsterdam. The sketchbook mentions the sale of a painting by his son to a frame and panel maker Terheggere for eight guilders in 1657, and the previously mentioned sale of two paintings by his son to the Amsterdam art dealer Van Meldert in 1658 for 16 guilders (no sizes listed) ${ }^{78}$ De Wet must have also supplied many paintings to the art dealer Doeck, making it plausible that more than a few of the 292 works that were inventoried without the painter's name also came from De Wet's workshop. The art dealer Doeck sold paintings at an average of four guilders a piece. ${ }^{79}$ These amounts give an idea of De Wet's retail prices.

The manifold anonymous versions of De Wet's paintings could have been created in the master's workshop by pupils, and sold as (cheaper) reproductions for the art market, or were produced at the instruction of art dealers operating in the art market itself. As stated, Meijeringh appears to have kept paintings from De Wet's workshop in his attic to be copied by his own employees. Gael's inclusion of elements from the prototype of The triumph of Mordecai, however, suggests that these designs were also present in De Wet's workshop.

The numerous pupils listed in De Wet's administrative notes and the painters slaving away at the copies for art dealers indicate an enormous production potential. The lack of identifiable works by the vast majority of these painters suggests that they participated in a large, predominantly anonymous production process.

\section{Conclusion}

De Wet produced three types of paintings: history paintings signed by himself, simplified versions of the former by anonymous pupils and assistants, and free variants signed by more advanced employees like Gael and Verdoel. Next to these, there are signs of a production line in the art market, but it remains unclear if De Wet had control over this. The different types of paintings were all produced in a similar style, technique and composition, with repeated backgrounds and figures. De Wet sold his own works and those of his assistants to art dealers in Amsterdam, who distributed them further.

The simplified versions of De Wet's originals are typically unsigned and are the result of different hands repeating the same composition on standardized supports, often for many 
years. The painters presumably worked after a drawn design or a painted prototype. The proportions of the composition and the characters remained intact across the different formats, which suggests the use of a grid or another copying device. No underdrawings were revealed by an infrared study of the privately owned The feeding of the five thousand and Solomon blessing David as his successor on the instigation of Bathsheba (figs. 18 and 29). Yet, no alterations in the painting process are visible, and the figures and outlines were applied directly on the ground. This indicates that the painter had a clear model in mind. The underdrawing or grid was presumably applied in a material that is not detectable with infrared imaging, such as red or light crayon.

De Wet's advanced pupils, Gael and Verdoel, adopted compositions, motifs and figures from designs or prototypes by De Wet, but they also made adjustments and additions. In these signed works we probably see the consequences of the Haarlem guild regulations, which clearly stated that every painter had to work at least one year under the instruction and in the style of a master painter as a vrije gast, before they could work independently. Their works were sold by their master but signed with their own names. This explains why these paintings ended up in the same Amsterdam art dealer inventories as De Wet's autograph works. The signed works by Gerrit de Wet and Jacob de Wet (II) are also based on De Wet's compositions. They might have had a substantial role in the workshop, because of family ties.

This research into the free variants and mass-produced copies of De Wet's workshop sheds light on methods of serial production. In many paintings associated with De Wet's circle, we find the same figures and background elements. These motifs were constantly reused and repurposed for different narratives. De Wet's workshop repeatedly used bystanders that were non-specific to the scene, such as a woman with child or a crying man. Characters more central to the narrative were also repurposed for other scenes. For example, the kneeling lady with her train held by servants was used for The queen of Sheba visiting Solomon and David as his successor on the instigation of Bathsheba (figs. 27-28 and 29-31).

Entire compositions were also repurposed. In De Wet's works minor characters and bystanders were often positioned closely around the main figures. The few characters outside the main group take part of the background and likewise painted in a wet-in-wet technique. This type of pictorial arrangement provided the workshop with a flexible adaptation of the composition for other scenes. The standing figure of Christ and the mountainous landscape in The feeding of the five thousand, for example, could easily be transformed into Moses and the Red Sea with Mount Sinai for Pharaoh's army engulfed in the Red Sea (figs. 16-19 and 2122). These dense figure groups were reserved in the background and dead-colored before the 
actual subject was decided. This way De Wet could produce quickly and steadily, while taking current demands into consideration.

The production of the same scene in a limited number of sizes by different hands and over a longer period of time is typical of mass production. It recalls fifteenth- and sixteenthcentury commercial workshops, in which a limited number of well-chosen compositions with a simplified design was endlessly repeated in standardized sizes with the use of patterns and models. I have shown that this manner of production was continued in the seventeenth century. The lower ranks of the art market remain invisible all too often, but for contemporaries, these type of paintings must have been a common-day sight.

\section{ABOUT THE AUTHOR}

Angela Jager (1984) is a postdoctoral researcher (Marie Skłodowska-Curie Individual Fellow) at the Statens Museum for Kunst in Copenhagen, Denmark. She studies the dispersal of Dutch paintings in Denmark, and focuses on a private collection of hundreds of undocumented paintings. In 2016, Jager successfully defended her dissertation about the mass production of history paintings in seventeenth-century Amsterdam (University of Amsterdam), to be published by Amsterdam University Press.

\section{AUTHOR'S NOTE}

Due to copy right permissions, this free version does not include the figures.

\section{ACKNOWLEDGEMENTS}

The article is a revised version of a chapter in my unpublished dissertation 'Galey-schilders' en 'dosijnwerck.': De productie, distributie en consumptive van goedkope historiestukken in zeventiende-eeuws Amsterdam (University of Amsterdam 2016), pp. 90-108. The entire dissertation, including this chapter, benefitted from the supervision of Eric Jan Sluijter, Marten Jan Bok and Harm Nijboer. As a postdoctoral researcher at the Statens Museum for Kunst (Copenhagen, Denmark), I have been able to investigate several of the discussed paintings (see notes 22 and 27). This project has received funding from the European Union's Horizon 2020 research and innovation programme under the Marie Skłodowska-Curie grant agreement no. 753496. I would like to thank Jørgen Wadum for his effort and help with the technical investigation of these paintings, and for his comments on a first draft of this article. I 
am furthermore indebted to Erin Travers for proofreading the final draft and providing helpful corrections and suggestions to the text.

1. I. van Thiel-Stroman, 'Biographies 15th-17th century', in: N. Köhler (ed.), Painting in Haarlem: 1500-1850: The collection of the Frans Hals Museum, Haarlem 2006, pp. 337-341.

2. A. Jager, 'Galey-schilders' en 'dosijnwerck. ': De productie, distributie en consumptie van goedkope historiestukken in zeventiende-eeuws Amsterdam, unpubl. diss, Amsterdam 2016, pp. 365. There is no further archival evidence of Jan de Wet's life, besides the patronym of De Wet's father. However, a painting and two drawings bear the signature Jan de Wet, one of which dates from 1618, and excludes authorship by Jacob de Wet: Jan de Wet, David and Abigail, signed by Jan de Wet and dated 1618, panel, c. 67 x 75 cm, sale London, Sotheby's, 1950-7-26, lot 39. Jan de Wet (here attributed to), The feeding of the five thousand, monogrammed 'JDW' and signed and dated bottom left 'Jan de Wet inventor 1635', paper, $26.5 \times 51 \mathrm{~cm}$, and The feeding of the five thousand, monogrammed bottom left 'JDW', paper, 27.5 x 51.9 cm, Brussels, Royal Museums of Fine Arts of Belgium, inv. 4025 and 4026. As Michiel Plomp has argued, the signature 'Jan de Wet inventor' and the monogram 'JDW' differ from any we know by Jacob de Wet. A drawing in the same style at the Teylers Museum bears the same monogram and the date '2-10-1601' on the reverse. Plomp proposes that they were drawn by one of De Wet's (unknown) brothers, but I suggest that they were produced by Jan de Wet, the grandfather of the painter. See M. Plomp, The Dutch drawings in the Teylers Museum, vol. II: Artists born between 1575 and 1630, Haarlem 1997, pp. 461462, cat. 554.

3. H. Miedema, De archiefbescheiden van het St. Lukasgilde te Haarlem 1497-1798, Alphen aan den Rijn 1980, pp. 1036.

4. Haarlem, Noord-Hollands Archief (NHA), Kennemer Atlas te Haarlem, inv. 53-999002K. Partially transcribed and published, see A. Bredius, 'Het schetsboek van Jacob de Wet', Oud Holland 37 (1919), pp. 215-222.

5. Van Thiel-Stroman 2006 (note 1), pp. 338. De Wet was appointed vinder in 1645 and 1661, and deken in 1662: Miedema 1980 (note 3), pp. 612, 671-672. 
6. F. Lammertse, 'Het kunstbedrijf van Gerrit Uylenburgh tussen 1655 en 1675', in: F. Lammertse and J. van der Veen (ed.), Uylenburgh \& Zoon: Kunst en commercie van Rembrandt tot De Lairesse 1625-1675, Amsterdam 2006, pp. 84-85.

7. Besides De Wet's brother and son, also his sister Maria de Wet married a painter: one of Jacob's former pupils, the still-life painter Adriaen Jansz. Kraen (c. 1619-1679).

8. For the payment to the Haarlem guild, see: Miedema 1980 (note 3), pp. 591-594, 666; Van Thiel-Stroman 2006 (note 1), pp. 339, n 4. Gerrit de Wet married Geertruyt van Tangeren in 1664 in Leiden: Leiden, Erfgoed Leiden en Omstreken, DTB, nos. 201, 1664-8-29; fol. 73v. For the full biography of Gerrit de Wet, see Jager 2016 (note 2), pp. 363-365.

9. Gerrit de Wet, The twelve year old Christ teaching in the temple, signed and dated 'Gerret de Wet Ao. 1640', panel, 60.5 x 84.5 cm, sale Cologne, Lempertz, 1927-3-23, lot 346; Saul welcoming David after his victory over Goliath, signed and dated bottom left 'G.d.Wet.F.1640', panel, 61 x 84.5 cm, Amsterdam, Rijksmuseum, inv. SK-A-1854. Van Thiel-Stroman 2006 (note 1), pp. 339, n 4; Miedema 1980 (note 3), pp. 591-594, 666.

10. The most recent biography of Jacob de Wet (II) in Jager 2016 (note 2), pp. 369-373, includes additions and rectifications of Van Thiel-Stroman 2006 (note 1), pp. 341.

11. Jacob de Wet (II) and his wife Helena Stalmans moved to Amsterdam between 27 April and 13 July 1668, see Van Thiel-Stroman 2006 (note 1), pp. 341.

12. Commissions included decorations and paintings for Holyroodhouse, Balcaskie House, Kellie Castle and Glamis Castle, see Jager 2016 (note 2), pp. 369-373.

13. Jacob de Wet (II), signed and dated on vase 'DE WET 1670', Portrait of a father and child with goat in a park, canvas, 68 x 53 cm. Sale London (Sotheby's), 2004-7-22, lot. 398.

14. W. Sumowski, Gemälde der Rembrandt-Schüler, 6 vols., Landau/Pfalz 1983-c. 1994, vol. 4, pp. 2778-2788. There is no updated catalogue raissonné of paintings by Jacob de Wet. This article accepts only signed paintings. 
15. Like most seventeenth-century painters, De Wet owned prints. The record of a wager with Cornelis Coelenbier in 1636, probably a relative of landscape painter Jan Coelenbier (16191680), that involved a print by Albrecht Dürer and two by Rembrandt. Bredius 1919 (note 4), pp. 216; Haarlem, NHA, inv. 53-999002K (note 4), fol. 63.

16. According to the documentation at the RKD the date of the painting is 1637 . However, on the available photographs only the signature and 'Ao' is visible.

17. The overlay was made by Valerio Pilo and the author on 28 August 2018 using Adobe Photoshop CC 2017.

18. Presumably, the figures 7 and 8 were of the same size. Figure 7 appears cut on top.

19. On reproduction techniques for mass production, see P. van den Brink, 'De kunst van het kopiëren: Het waarom en hoe van het vervaardigen van kopieën en schilderijen in oplage in de Nederlanden in de zestiende en zeventiende eeuw', in: P. van den Brink (ed.), De Firma Brueghel, Maastricht/Brussel 2001, pp. 12-43.

20. E. van de Wetering, 'Rembrandt's prototypes and pupil's production of variants', in: E. van de Wetering e.a., A Corpus of Rembrandt paintings V: Small-scale history paintings. Dordrecht 2011, pp. 259-261.

21. The subject The feeding of the five thousand is unusual and not mentioned in the subject index of E.J. Sluijter, Rembrandt's rivals: History painting in Amsterdam 1630-1650, Amsterdam 2015, pp. 482-485, and only mentioned as by Jacob de Wet in the subject index of Sumowski 1983-c. 1994 (note 14), vol. 5, pp. 3417, 3398-3438. Two drawings of this subject are unconvincingly attributed to De Wet, and here attributed to his grandfather Jan de Wet. See note 2.

22. For privacy reasons the name and location of the painting remains unknown. The infrared imaging was carried out on location by Jørgen Wadum and the author with an Artist PRO camera mounted with a CCD progressive scan image sensor (1360 x 1036 pixels) and a Schneider Kreuznach Xenoplan 23 mm F/1.4 CCTV lens in near Infrared 2 with a long wave 
pass filter $1000 \mathrm{~nm}$. The images were captured with Artist software (release 1.2) and assembled with Adobe Photoshop CS6 with photo merge function (reposition parameter).

23. Sluijter 2015 (note 21), pp. 230-231.

24. Sluijter 2015 (note 21), pp. 244-246.

25. Sluijter 2015 (note 21), pp. 205-207, 247-246, 294. The possibility that De Wet and De Poorter visited Uylenburgh's studio was also suggested by Sumowski 1983-c. 1994 (note 14), vol. 4, p. 2723, J.M. Montias, Art at auction in 17th-century Amsterdam, Amsterdam 2002, pp. 123, and J. van der Veen, 'Het kunstbedrijf van Hendrick Uylenburgh in Amsterdam: Productie en handel tussen 1625 en 1655', in: Lammertse en Van der Veen 2006 (note 6), pp. 117-205, 190. Adriaan Waiboer argued that De Poorter may have briefly worked under the supervision of Rembrandt in the mid-1630s, see A.E. Waiboer, 'Willem de Poorter: Rembrandt/Not Rembrandt Pupil', Journal of Historians of Netherlandish Art 5 (2013), no. 2: DOI: 10.5092/jhna.2013.5.2.12.

26. This painting is part of the same private collection as The feeding of the five thousand and investigated in a similar manner, see note 20.

27. The infrared imaging was carried out by Jørgen Wadum and the author with an Osiris camera with an InGaAs array sensor, wavelength 0,9 -1,7 $\mu \mathrm{m}$. Camera lens: Rodagon f:150mm focal length F/1:5,6 with an aperture of f:16. Light: 2 halogen 1000w light Hedlerlamps from $200 \mathrm{~cm}$ distance. The image is composed by a series of parallel exposures, each 3000x3000pixel, assembled on a PC using Adobe Photoshop CS6 with photo merge function (reposition parameter). The technical investigation took place at the Statens Museum for Kunst in June 2015, during a residency at the Centre for Art Technological Studies and Conservation (CATS) with fellowships from the Historians of Netherlandish Art and the Kircheiner-Galatius Fonds.

28. The drawing, falsely signed by a later hand 'G. van den Eeckhout', was convincingly attributed to De Wet in W. Sumowski, Drawings of the Rembrandt School, 10 vol., 19791992, vol. 10, cat. 2377. Sumowski identifies the drawing incorrectly as Joseph sells corn in Egypt. De Wet used the same composition and elements for the subjects Joseph sells corn in 
Egypt and The queen of Sheba visiting Solomon, but distinguishes the queen of Sheba by surrounding her with gifts instead of children. The drawing therefore certainly represents The queen of Sheba visiting Solomon.

29. The only photograph of this painting in the collection of RKD describes its whereabouts as 'collection Tharandt'. The painting is therefore identical to the painting previously in the collection of Count Leszczyc-Sumiński at Schloss Tharandt (Dresden), and sold at auction in München, 1907-10-4, lot 173 (as Johann de Wet).

30. A. Tummers, “'By his hand.' The paradox of seventeenth-century connoisseurship', in: A. Tummers and K. Jonckheere (ed.), Art market and connoisseurship: A closer look at paintings by Rembrandt, Rubens and their contemporaries, Amsterdam 2008, pp. 31-66.

31. Haarlem, NHA, inv. 53-999002K (note 4). Partially transcribed and published, see Bredius 1919 (note 4), pp. 215-222.

32. The biblical scenes in this sketchbook are currently being studied by Alexander de Bruin in connection to six paintings by Jacob de Wet in the Sint-Elisabeth's or Groote Gasthuis in Haarlem.

33. The appendix contains my own transcription of De Wet's administrative notes, Haarlem, NHA, inv. 53-999002K (note 4), identification of the names based on information in the RKDartists database and Miedema 1980 (note 3), and translations of the rates for instruction into annual fee in guilders. Several listings are illegible, as they were in Bredius'time, see Bredius 1919 (note 4).

34. Miedema 1980 (note 3), pp. 1036. De Wet was listed in the guild records of 1637 as left ('vertrocken'), see Miedema 1980 (note 3), p. 423.

35. This page of the sketchbook is missing for precise dating.

36. R. de Jager, 'Meester, leerjongen, leertijd: Een analyse van zeventiende-eeuwse NoordNederlandse leerlingcontracten van kunstschilders, goud- en zilversmeden', Oud Holland 104 (1990), pp. 69-110, esp. pp. 75-79. Relevant information about the conditions of these 
apprenticeships is lacking. De Jager concluded that long-term training contracts had lower fees than short-term contracts, and in order to fully assess the fee, the financially responsible party concerning the raw materials versus that of the finished products (pupil or master) was also relevant.

37. This fee was reported by Joachim von Sandrart, Teutsche Academie der Bau-, Bild- und Mahlerey-Künste, 3 vols., Nürnberg 1675, vol. 2, book 2, pp. 326. Receipts for instructing his pupil Isaak Jouderville between november 1629 and november 1631 with a total of 200 guilders attests to this fee. W.L. Strauss and M. van der Meulen, in collaboration with S.A.C. Dudok van Heel and P.J. de Baar, The Rembrandt documents, New York 1979, no. 1630/2, 1630/4, 1631/3, 1631/7, 1631/9, 1631/10.

38. The listings in the sketchbook are 'jaer 1642 / den 12 may is P potter bij mijn te schilderen gecoomen voor de soma van acht pont int jaer' and 'den 2 november is bij mijn te tekenen gekoomen Job Adriaensen van Berckheyde Ao 1644', Haarlem, NHA, inv. 53-999002K (note 4), [fol. 65v]; Bredius 1919 (note 4), pp. 217. The 'P' before Potter appears a later addition.

39. Sluijter 2015 (note 21), pp. 317-318, n 174; A. Walsh, Paulus Potter: His works and their meaning, Ann Arbor 1991, pp. 116-131.

40. 'Een historie van de rentmeester in ebben lijst, van Jop Bercheijer'; Amsterdam, Stadsarchief Amsterdam (SAA), notarial archives no. 1202; fol. 270-286; 281; The Montias Database of 17th Century Dutch Art Inventories, New York, The Frick Collection, Montias database, inv. 184.

41. Berckheyde was asked to pay his guild entrance fee on 10 June 1653 , but only paid on 10 March 1654: Van Thiel-Stroman 2006 (note 1), pp. 107.

42. Job Berckheyde, Christ blessing the children, signed and dated bottom right ' $\mathrm{J}$ Berckheyde Ao 1662', canvas, 52 x 68 cm, Schwerin, Staatliches Museum Schwerin, inv. G441. Many thanks to Gero Seelig for verifying the signature and date.

43. Miedema 1980 (note 3), pp. 666, 936. 
44. Boers-Goosens names Rochus van Veen among these amateurs. However, Van Veen also paid for room and board, and he must have been serious about his education: M. BoersGoosens, Schilders en de markt: Haarlem 1605-1635, Leiden 2001, pp. 100. About Rochus van Veen, see: E.J. Wolleswinkel, 'De dagboeken van de genealoog Pieter van Brederode van Wieringen (1631-1697)', De Nederlandsche Leeuw 123 (2006), pp. 339-344; J. van der Veen, 'Voor eigen plezier: Rochus van Veen ca. 1618-1693', Kunstschrift 52 (2008), pp. 34-37. The auction of his estate of drawings, prints and some paintings initiated in Haarlem on 23 September 1709: A. van der Willigen Pz., Les artistes de Harlem: Notices historiques avec un précis sur la gilde de St. Luc, edition revue et augmentée, Haarlem/The Hague 1870, pp. 302; Miedema 1980 (note 3), pp. 749, n 275.

45. The relocation of Kort Withold from Philips Wouwerman to Jacob de Wet disolved into a dispute with the Haarlem guild, in which Withold admits that he had already made a start with the painting of a trony ('een trony had gedootverft') in Wouwerman's studio. Van ThielStroman 2006 (note 1), pp. 338. Miedema 1980 (note 3), pp. 508-509. Nicolaes Berchem paid the guild contribution for Guilljeam le Febre on 2 September 1642: Miedema 1980, pp. 543, 546, 549; Van Thiel-Stroman 2006, pp. 102. Le Febre was listed in De Wet's sketchbook on 5 May 1643 as 'came to draw' ('te tekenen gekomen') and on 8 September 1643 as 'starting to paint' ('aen schilderen gegaen').

46. A. Blankert, Nederlandse 17e eeuwse Italianiserende landschapschilders, Soest 1987, pp. 147-149; P. Biesboer, 'Nicolaes Pietersz. Berchem, meester-schilder van Haarlem', in: P. Biesboer (ed.), Nicolaes Berchem: In het licht van Italië, Haarlem 2006, pp. 10-37, 21.

47. The full listing in the sketchbook is 'Ariaen Gael is alhier te schilderen gekoomen den 17 april int jaer 1640 voor de soma van 8 pont sj[aers]': Haarlem, NHA, inv. 53-999002K (note 4), [fol. 65], Bredius 1919 (mote 4), pp. 216.

48. Jager 2016 (note 2), pp. 308.

49. Adriaen Gael, David with the head of Goliath, signed and dated bottom middle 'A. Gael 1643', panel, 49.5 x 69 cm, sale Bremen, Bolland \& Marotz, 2014-11-08, lot. 1634; Joseph in 
the well, signed and dated bottom left 'A. Gael 1644', support and size unknown, sale Keulen, Van Ham, 2001-09.

50. The testament of his parents Adriaen Gael (I) and Marritje Kampers was drawn up in 1644, and states that Adriaen Gael (II) (named 'de Jonge') would inherit 'all the paintings and the rest belonging to it' ('alle de schildercunst ende tgeen daer toe behoort'). This testament was changed in 1652: Gael would receive 1500 guilders and 'all that is granted to the art of painting, as prints, drawings and others belonging to it' ('alle het gunt totte Schilderkunst, soo van prenten, teeckeningen en de andere behoorende is'). The Hague, RKD, RKDcollections, archive A. Bredius, no. NL-HaRKD.0380, 'Gael', fol. 9, 1644-4-18 (Haarlem, NHA, original not traced), fol. 1, 1658-12-17 (Haarlem, NHA, notarial archives, no. 283, fol. 237v-238), fol. 20, 1651-9-10 (Haarlem, NHA, notarial archives, no. 198, fol. 45), and 1660-2-18 (Haarlem, NHA, original not traced). For the full biography of Adriaen Gael (II), see Jager 2016 (note 2), pp. 308-309.

51. For his oeuvre, see Jager 2016 (note 2), pp. 379-384.

52. For the full biography of Adriaen Verdoel, see Jager 2016 (note 2), pp. 354-357.

53. The full listing in the sketchbook is 'den 16 junius is bij mijn gekomen Ariaen Verd[oel] om te leren schilderen v[oor] de soma van 48 guld[en]': Haarlem, NHA, inv. 53-999002K (note 4), [fol. 65v], Bredius 1919 (note 4), pp. 216.

54. Arnold Houbraken wrote that Adriaen Verdoel was trained by Rembrandt, but admits in the same sentence that others believe his masters to be Leonaert Bramer and Jacob de Wet, see A. Houbraken, De groote Schouburgh der Nederlantsche konstschilders en schilderessen, 3 vol., Amsterdam 1718-1721, vol. 2, pp. 57. It is unlikely that Verdoel trained with Rembrandt before his training at De Wet. Verdoel grew up in Schiedam, and could have had his basic training in the nearby city of Delft, perhaps at Bramer. There are no sources to confirm this. Verdoel lived in Haarlem from 1641 to 1654, and moved to Vlissingen after.

55. RKD, RKDcollections, archive A. Bredius, no. NL-HaRKD.0380, Haarlem 'W', fol. 2, 112-1644 (Haarlem, NHA, original not traced) and 'De Wet' , fol. 13, 1646-7-10 (Haarlem, NHA, original not traced). 
56. Miedema 1980 (note 3), pp. 654, 1033.

57. A first reconstruction of his oeuvre is attempted in Jager 2016 (note 2), pp. 385-389.

Verdoel's oeuvre is quite problematic, because the signed and dated paintings point to at least two painters active with the same name. Adriaen Verdoel (I) died in 1675 in Vlissingen. The paintings dating between 1690 and 1700 are therefore identified as by Adriaen Verdoel (II). On reflection, the painting Peasants drinking in an interior, signed and dated 'A. Verdoel $\mathrm{f}$ 1652', panel, 39.2 x 32 cm, sale Amsterdam, Christie's, 2013-11-20, lot 15, matches the production of Verdoel (II) rather than Verdoel (I). The date might have been mistakenly read as 1652. However, a genre painting with dancing people in old-fashioned clothing, signed and dated 'Adria Verdoel 1643', differs completely in character, subject and style from the works of either, see illustration in S. Rosenthal, Art in America 17 (1929), pp. 250. Could this genre painting be by yet another Adriaen Verdoel?

58. Boers-Goosens 2001 (note 43), pp. 74-79. This type of apprenticeship might have been common practice.

59. Boers-Goosens 2001 (note 43), pp. 79. Painters employed in Utrecht workshops were obligated to paint in the master's manner, see S. Muller Fz, Schilders-vereenigingen te Utrecht: Bescheiden uit het gemeentearchief, Utrecht 1880, pp. 78.

60. Sluijter 2015 (note 21), pp. 331.

61. See note 39. Van Meldert's inventory states that Berckheyde had to be paid out of the estate (Job Bercheyden schilder moet hebben [amount left blank]): for delivered work? Amsterdam, SAA, notarial archives no. 1202; fol. 285.

62. The inventory is numbered: ' 24 een lantschap in een ebben lijst, van Jacob de Wet', '48 een ovael in een lijst, gecopieert na de Weth', '53 een schilderij van een karsnaght in een ebben lijst, van Gerrit de Wet' and ' 66 een histori, van Gaal, sonder lijst'. Amsterdam, SAA, notarial archive, no. 1202, fol. 270-286; 280, 280v, 281. Transciptions of the paintings in this inventory are published in A. Bredius, Künstler-Inventare: Urkunden zur Geschichte der 
holländischen Kunst des XVIten, XVIIten und XVIIIten Jahrhunderts, 8 vols., Den Haag 19151922, vol. 6, pp. 1968-1973, and The Montias Database (note 39), inv. 184.

63 'ghelevert aen Sr Pieter van Melder twe stucks van mijn soon voor de soma van 16 gulde Ao 1659', Haarlem, NHA, inv. 53-999002K (note 4), [fol. 63v]. Bredius 1919 (note 4), pp. 217. Irene Van Thiel-Stroman interpreted the amount as 56 gulden: Van Thiel-Stroman 2006 (note 1), pp. 342, n 3.

64. The listings in the Hals inventory are 'een historie van Jacob d'Wett d'jonge', 'een do van de selve' and 'een storij van d'Wet', Amsterdam, SAA, notarial archive, no. 2617, 1662-3-30, unpaged. Transciptions of the paintings in this inventory are published in Bredius 1915-1922 (note 61), vol. 2, pp. 451-453 and The Montias Database (note 39), inv. 411.

65 A. Jager, "Everywhere illustrious history paintings that are a dime a dozen": The mass market for history painting in seventeenth-century Amsterdam', Journal of Historians of Netherlandish Art 7 (2015), no. 1: DOI: 10.5092/jhna.2015.7.1.2. Jager 2016 (note 2), pp. 23 50.

66 The total amount of paintings differs here from Jager 2015 (note 64) after a recount for Jager 2016 (note 2).

67 This number amounts to thirty paintings if we include Berckheyde and Potter, who are both represented with one painting in Doeck's shop.

68. The listing in the sketchbook is ' 3 julius is by myn te schilderen ghekomen Pieter Wiggerts voor de soma van 60 gulde jaers int jaer 1656', Haarlem, NHA, inv. 53-999002K (note 4), [fol. 64v], Bredius 1919 (note 4), pp. 217.

69 Pieter Wiggersz. was registered in the workshop of Jacob de Wet on 3 July 1656 and registered as member to the Haarlem Lutheran Church one month later; Haarlem, NHA, 2142, DTB, no. 111, fol. 511, 1656-8-20. Wiggersz. intended marriage contract in 1664 states an address on the Amsterdam Breestraat, which was just a few minutes away from Doeck's shop: Amsterdam, SAA, DTB, no. 686, fol. 69, 1664-4-19. It is therefore possible that these paintings entered Doeck's shop through direct contact with the painter instead of through De 
Wet's business. Wiggersz. came from Gdańsk, as Doeck's parents. For the full biography of Pieter Wiggersz., see Jager 2016 (note 2), pp. 373-374.

70 Of the 26 paintings, 22 were found on the attic. See also A. Jager, 'Barend Jansz. Slordt (ca. 1625-na 1690), 'galey-schilder' uit Schermerhorn', Oud Holland 127 (2014), pp. 223 233.

71 The inventory of Doeck's paintings mentions an attic, and lists most of the paintings here. However, this inventory was written by different hands on different days and is inconsistent in the amount of detail and information given. The attic is one of the rare rooms mentioned.

72 For publications about the standard sizes, see J. Bruyn, 'Een onderzoek naar 17de-eeuwse schilderijformaten, voornamelijk in Noord-Nederland', Oud Holland 93 (1979), pp. 96-115; H. Miedema, 'Verder onderzoek naar zeventiende-eeuwse schilderijformaten in NoordNederland', Oud Holland 95 (1981), pp. 31-49.

73 Boers-Goosens 2001 (note 43), pp. 287.

74 On the pricing of paintings in De Wet's segment, see Jager 2015 (note 64), par. 30-44.

75 Boers-Goosens 2001 (note 43), pp. 287.

76 The exact listing of the costly Europa made for Van der Stel ('Noch een stuck van Uropa gemaeckt voor menheer Van der Stel daeraen verdient de soma van 100 gulden') suggests that it was painted on commission, which would justify its higher price compared to works painted for the studio's stock-in-trade (potentially by assistants). Van der Stel also purchased some smaller works at a lower price: 'een stuckie' depicting Christ's dispute with the doctors in the temple for thirty guilders and 'een brantie en een lantschapie' for fifty guilders, see Bredius 1919 (note 4), pp. 219.

77 Miedema 1981 (note 71), pp. 33-34, table 2 and 3. 
78 'den 6 maert Ao 1657 aen Barent Jans ter heggere verkoft [....] noch een stuck van mijn soon van 8-0-0', Haarlem, NHA, inv. 53-999002K (note 4), [fol. 63v]. This note was not transcribed by Bredius 1919 (note 4), pp. 217.

79 Jager 2015 (note 64). 